\title{
ON THE METHODS OF CONSTRUCTING A MYTHOLOGICAL TEXT: SLAVIC FOLK BELIEFS REGARDING THE SPOTS OF THE MOON
}

\author{
Aleksandr Gura
}

\begin{abstract}
The dark spots visible on the surface of the full Moon have been diversely interpreted in the Slavic folk calendar, with a partial overlapping being noted upon the consolidation of relevant thematic groups. The article provides an overview regarding the explanations, concerning the origin of lunar spots, widespread among the Slavic people. The comparative analysis of the Slavic narratives on lunar spots indicates the distribution of the text into different morphological elements, enables the ascertaining of mutual correlations and combinations, and shows how they are being used to "assemble", construct texts in different regional traditions, determining the "grammatical" structure of the mythological text as a whole.
\end{abstract}

Key words: mythology, lunar spots, Slavic folklore

Different interpretations, within the Slavic folk calendar, attributed to the dark spots visible on the surface of the full Moon, can be consolidated into several partially overlapping thematic groups.

\section{ASSOCIATION OF LUNAR SPOTS WITH DIRTINESS}

The first group of interpretations (mainly among the Bulgarians, and partially among the Macedonians and Croatians) is associated with cows and cow dung. Pursuant to such explanations, the stains on the Moon are either a cow with a large udder (Mazneva 1946: 109) or a pear tree emptied of the fruit by God's cow which thereafter became a Moon (ArhEIM 879-II: 72). Most frequently, however, the stains are the traces of a cowpat or ox faeces. The Moon thrown on the earth by a witch had stained itself in the cowpat excreted by a cow passing the Moon (ArhEIM 881-II: 108), or the cowpat was thrown on to the Moon in order for the latter not to shine as brightly. (ArhEIM 879-II: 31; ArhEIM 880-II: 46; Rodopi 1994: 11; Khristova 1941: 117; Velcheva: 48; Janković 1951: 109). Customarily, the cow dung was thrown onto the Moon by a girl (in many 
instances, a bride) who had been spending time with her beloved one (Velcheva: 48), sowing or weaving (Milenkova 1943: 131; Ivanova 1937: 58; Arakchieva 1939: 92; Penushliski 1969: 26; Majzner 1939: 152), working in the field at night (Mazneva 1946: 108), or hitting herself against the low-lying Moon while approaching the water (Pencheva 1940: 128-129; Trifonova 1945: 158). Sometimes, it is the Sun who does the throwing - envying the Moon shining more brightly (Nenov 1939: 102; Mazneva 1946: 108; ArhEIM 881-II: 5, 55; ArhEIM 878-II: 6, 49, 72; Mikhailova 1985: 171; Rodopi 1994: 11; Kr"steva 1943: 128129; Đorđević 1958: 30; Cf. also Georgieva 1983: 23; Vakarelski 1977: 414) or as a revenge for the Moon not marrying him (Mikhailova 1985: 151, Rodopi 1994: 11; Kasabova 1940: 122).

In addition, Bulgarians explain the origin of Moon spots by wiping the hands in the Moon - thus it is the trace of dough, dirt or hands soiled with excrement, left by a woman who had wiped her hands on the low-lying Moon after kneading (Georgieva 1983: 23), washing the diapers (Ilieva 1941: 127) or wiping the bottom of an infant (Velcheva: 49; ArhEIM 880-II: 4; Georgieva 1983: 23).

\section{PEOPLE ENDING UP ON THE MOON}

Bulgarians, and partially also Russians, interpret the Moon stains as a boy and girl in love - going to fetch water, in most instances. Among the Russians living in the North, these are a boy and a girl going to get water (VGU, Ludnikova 1923: 3) or a girl carrying buckets (Belova 2004: 521), whereas according to Bulgarians, the spots of the Moon are a girl, carrying buckets, and a boy on their love tryst (Trifonova 1945: 158), and sometimes merely a girl with shoulder poles and buckets (Georgieva 1983: 23; ArhEIM 576-II: 21M; Kr"steva 1943: 128-129). Pursuant to some interpretation variants, the girl is giving the boy some water to drink from the bucket (Milenkova 1943: 132; Pasheva 1983: 99) or kissing him (Pencheva 1932: 89). The boy, loved by the maiden (Trifonova 1945: 158; Anchev 1980: 63; Fand"kova 1937: 27), is sometimes a shepherd (Mazneva 1946: 109), a poor one (Pencheva 1932: 89) or a relative fallen for the girl (Pasheva 1938: 99). The image of a girl in shoulder poles is also known among the Volyn' Ukrainians (Belova 2004: 519).

The central figure in the Russian and South-Slavic tradition is the smith: among Russians, two smiths are forging stars on the Moon (Kolchin 1899: 7); ${ }^{1}$ according to the elucidation of the Serbians, there is a smith on the Moon on festal days, forging keys (Janković 1951: 109); the Croatians have the smith Vid (cf. St. Vitus - the patron saint of smiths in some South-Slavic tradition 
(Tolstaia 1995: 369)), who has taken the devil as his apprentice (Đorđević 1958: 31); Bosnian Muslims have a smith of another faith who always halted his hammering on the anvil for the time being when the mullah asked to convene for a prayer in the minaret (Đorđević 1958: 31); Serbians have a Gypsy smith who hits the anvil with the hammer, thereby making the Moon shine more opaquely than the Sun (Đorđević 1958: 31; Janković 1951: 109).

Likewise, Gypsies are also present in other Southern and Eastern Slavs, with regard to the imagination of lunar spots. According to the beliefs of Croatians and Bosnians, one can see a Gypsy, with an anvil and a hammer, on the Moon, having used the latter to kill his peasant relative amidst an argument (Đorđević 1958: 31-32); a hanged Gypsy figures in the folk tradition of Bulgarians (Vakarelski 1977: 414) or a Gypsy with a mirror which he turns on us during the full moon, and away at other times (Georgieva 1983: 23; Vakarevski 1977: 414, see also Rodopi 1994: 11); yet, according to the belief of Russians, it is a Jew and a Gypsy who feature on the Moon (AKTE, Volgograd oblast).

The next in the sequence of explanatory groupings, prevalent among the Bulgarians and western Slavs, is associated with theft, thieves and stolen items. In the opinion of Bulgarians, the spots on the Moon are generated by honey stolen by the Moon (Georgieva 1983: 23); a trace left by a cowpat used by a girlthief to attack the Moon in order for the latter not to stop her stealing (V"glenov 1936: 16) or a boy with a stolen plough (Georgieva 1983: 23; Vakarelski 1977: 414). The Czechs and Polish people can see a pea thief or manure stealer on the Moon (Afanas'ev 1944: 25; Wasilewski 1989: 190-191), the Sorbians envisage a woman with a basket on her back filled with stolen eggs (Czerny 1895: 56), the Czechs a thief on Christmas Eve with a stolen armful of firewood (Afanas'ev 1944: 251); the Poles living on the German border - a thief with a bunch of pea tendrils to cover the Moon in order for the latter not to prevent him from stealing (Wasilewski 1989: 191).

Several interpretations, particularly these of the Poles, involve the motif of labouring during the feast days. The people who had been working either on Sundays or holidays can be seen on the Moon: in the case of Serbians, a woodcutter who had felled trees in the forest on Sunday, or a girl who had weaved in the moonlight on Sunday (Janković 1951: 109), in Polish tradition, a peasant with a bunch of brushwood or wood on his back (Szyfer 1975: 145; SSS 1996: 194; PAE map), a peasant sowing peas (Wasilewski 1989: 191), a man ploughing with oxen (Szyfer 1975: 145; SSS 1996: 194), ${ }^{2}$ an old woman making butter (Wasilewski 1989: 190; Szyfer 1975: 145), kneading dough in a vessel (Wasilewski 1989: 190; PTA EI 1145-I: 2), baking bread (Szyfer 1975: 145; SSS 1996: 194), weaving or spinning (Wasilewski 1989: 190; PAE map; see also Kuchta 1926: 46). 
A weaver or seamstress occur in some versions: in the case of Polabian Slavs, a woman on the Moon spins thread which falls on the earth as a cobweb at the end of summer (Afanas'ev 1994: 275; Kuchta 1926: 46); among Bulgarians and Serbians, a girl spins a tow (ArhEIM 881-II: 108; Janković 1951: 109), among Czechs and Poles, the prophet Sibyl sews a shirt, bringing the end of the world closer by way of every daily made stitch (Kuchta 1926: 46).

According to the Polish and Sorbian conception, a peasant with manure (or straw) can be seen on the Moon: a countryman is holding a spade he had used to throw out manure at Christmas time (Siarkowski 1885: 66); a peasant taking out manure on Sunday, spreading it with a pitchfork (Kolberg 1962d: 69; PTA EI 1145-I: 2; SSS 1996: 194; Kolberg 1962c: 5; PAE Upper Sorbians, Czerny 1895: 56); the head or face of this peasant (Czerny 1895: 56), and also his legs (Kolberg 1962a: 91); a peasant hanged on a pronged fork by Satan for the reason that he had moved the straw with his pitchfork at Christmas (PTA EI 1796: $6)$.

\section{PUNISHMENT FOR BUTCHERY}

The tradition associated with two brothers (frequently Cain and Abel) and fratricide is particularly widespread among the Slavic people. While sharing the property, the brothers tear a pot from each other's hands (among Bulgarians Kunov 1940: 117), a club (Ukrainians) or a pitchfork (Poles - Kolbuszewski 1895: 171). A brother kills his brother (often the rich one slaughters the poor brother) because of a hay or straw stack (Polesie Ukrainians and Belorussians - Belova 2004: 509; Agapkina 1993: 154), as a revenge for cutting hay from his land (Trans-Carpathian Ukrainians - Belova 2004: 519), when dividing the land and other property (among Ukrainians and Belorussians) (Belova 2004: 518519). One brother accidentally thrusts a pitchfork through the other one while loading the sheaves (Bulgarians - Mikhalev: 181), unloading hay or laying it out for the animals at Christmas, New Year, Epiphany or Easter time (by Ukrainians - Zaglada 1929: 137; Belova 2004: 516-517; Agapkina 1993: 154; Afanas'ev 1994: 251). Cain kills Abel (brother kills his brother): most frequently (among Eastern Slavs and partially also the Poles) by way of slaying him with a pitchfork (Zelenin 1991: 424; Kuchta 1926: 41-42; Dal' 1957: 922; Bernshtam 1988: 275; Afanas'ev 1994: 252; Agapkina 1993: 153-155, Belova 2004: 505-511, 515; Nikiforovskii 1897: 219; Federowski 1897: 149; Moszyński 1928: 156; Kuchta 1926: 45; Savchenko 1906: 106; Fischer 1909: 328; SSS 1996: 145; Kolbuszewski 1895: 171; Szyfer 1975: 145); and more seldom (e.g. among Trans-Carpathian Ukrainians) stabs him with a stake (Belova 2004: 509), kills him with an axe 
(among Russians and Belorussians - AKTE; Agapkina 1993: 153; Belova 2004: 509,516 ), hammer or shoulder poles (for Russians - AKTE), and also with a knife or a sword (among Serbians, Ukrainians, and partially also among Polesie Belorussians - Janković 1951: 108; Agapkina 1993: 153; Belova 2004: 516). According to the beliefs of the Russians, Cain carries the murdered Abel (brother) on his back or, having the dead brother on the scruff of his neck carries him from the Moon to the sea (AKTE; Zelenin 1914: 186; Belova 2004: 506, 514; Agapkina 1993: 155). Among Poles, Cain, regretting the fratricide on the Moon, performs a sacrifice together with Abel (RKA 8643 No J11). In some occasions (for Southern and Eastern Slavs) there is only Cain on the Moon, serving his punishment for fratricide (Đorđević 1958: 31; Vakarelski 1977: 414; Georgieva 1983: 23; Penushliski 1969: 25-26; Markevich 1860: 77; Kuchta 1926: 41; Afanas'ev 1994: 251), in Russian narratives, he sometimes has an axe with him (Belova 2004: 509), yet in the tradition of Ukrainians, Abel as the victim of Cain is also on the Moon (Belova 2004: 506). In addition to fratricide, it is possible to come across a few occasions of slaying other persons: a man kills his wife with a pitchfork (Belova 2004: 520), a father holds his son on a prong (Belova 2004: 520) or instead, the father is on the fork of his son (PA), a son stabs his father (Belova 2004: 520), a man holds a bear on top of a pitchfork (Belova 2004: 521).

\section{BIBLICAL CHARACTERS, SAINTS AND HISTORICAL FIGURES}

In a number of occasions, the lunar spots are associated with biblical figures and saints. Namely, according to the imagination of the Eastern Slavs, Adam and Eve can be seen on the Moon (AKTE; Belova 2004: 511; cf., e.g., in Chernigov oblast, Adam holds Eve on a pitchfork, Belova 2004: 511) or the God feeding the first people with bread (Dal' 1957: 922), in the opinion of Bulgarians, Adam and Eve boil milk in the cauldron (Telbizov \& Vekova-Telbizova 1963: 175). Serbians, on the other hand, see the icon of Matthew the Evangelist on the Moon (Đorđević 1958: 31; Janković 1951: 108), and Trans-Carpathian Ukrainians - the head of John the Baptist (Belova 2004: 514), Belorussians in the vicinity of Pinsk consider this to be a person with the chopped head of John the Baptist, or Abraham having sacrificed his son (Belova 2004: 513). Ukrainians of Trans-Carpathia also mention brothers Esau and Jacob, one of them with a pitchfork he had used for slaughtering his father (Belova 2004: 513). According to the Ukrainians in Eastern Polesie, the ones on the Moon are brothersmartyrs Azariah and Anani (Belova 2004: 514); Polesie Ukrainians and Russians consider this prophet Il'ia (Elias) on a cart or with a horse (Belova 2004: 
511, cf. also in Ivanovo region, Brest oblast, brothers Ivan and Lazar, one of them stabbing the other with a pitchfork - Belova 2004: 511); in the case of Poles - Saint George frightened by lightning (Kuchta 1926: 49; Gustawicz 1901: 134-135) or Saint Stefanos tasked with a duty to govern the Moon (Wierzchowski 1890: 189), and Russians - Archangel Michael or Gabriel who rule the Sun and the Moon (Bernshtam 1988: 275). Pursuant to Polish beliefs, Saint George plays the violin or lute on the Moon (Kolberg 1963b: 196; Ciszewski 1887: 3; Gustawicz 1901: 134-135; Udziela 1890: 133; Kolberg 1963a; SSS 1996: 194; Kuchta 1926: 48), ${ }^{3}$ in the opinion of Czechs, it is David playing either a violin or harp (Rikhlik 1928: 213; Afanas'ev 1994: 251), the Slovaks consider the harpplayer to be either Abram or David, asking the God to raise the mother from the inferno (Belova 2004: 512; Eljasz-Radzikowski 1899: 248); according to the beliefs of the Upper Sorbians, a musician plays to the God, God's Mother or the Holy Spirit in order to save his parents from the hell (Haupt \& Schmaler 1953: 387).

Yet in some beliefs, the featuring figures are the angel and the Satan. Pursuant to the interpretation of the Ukrainians and Bulgarians, the lunar spots denote a sinning angel (Belova 2004: 511), cursed by God for this and who thereafter became the Satan (Georgieva 1983: 23), among Serbians, an angel who had fallen from heaven, drunk water from the devil's spring, and was later caught on the Moon by Satan who had hit the angel, making a hole in his foot (Majzner 1934: 100-101; Đorđević 1958: 31; Kulišić et al 1970: 201; Janković 1951: 109), in the case of Bulgarians, a Satan (Vakarelski 1977: 414), among Bosnians, a chained Satan crucified by God (Đorđević 1958: 31; Janković 1951: 109).

Ultimately, lunar spots are also construed by way of historical figures sojourning on the Moon. Thus, according to the imagination of Polish people, the witch Tvardovski from Krakow can be seen on the Moon (Kuchta 1926: 49; Wójcicki 1972: 118; Kolberg 1962b: 228; SSS 1996: 194; Kolbuszewski 1895: 171), either smoking a pipe or making butter (SSS 1996: 194); or a devil holding the body of Tvardovski on his pitchfork (SSS 1996: 194) or King Vladislav who perished in 1444, in the war with Turks (Kolberg 1962c: 4-5; Kuchta 1926: 46). Russians identify the lunar spots with Peter the Great, or the tsars Ivan the Terrible and Peter the Great (AKTE), the Serbians, on the other hand, with the spotty head of King Marko's horse (Đorđević 1958: 31; Kulišić et al 1970: 201; Janković 1951: 108). 


\section{OTHER EXPLANATIONS}

Certain beliefs regarding the spots on the Moon form, however, a totally separate group. According to Kashubians, the spots are the traces of grease, used for smearing the celestial wheel (the Moon) of the carriage utilised by Archangel Michael to chase the devil during the war in the heavens (Sychta 19671976 (3): 281); pursuant to the Serbians, these are the bite-marks of a serpentlike monster ala (Kulišić et al 1970: 4), according to Bulgarians, the traces were left by the cloth used by a girl to dim the brightness of the Moon (Iavashev 1937: 182-183). Indeed, Bulgarians also believe that it is the head of a woodcutter on the Moon, and the wood-cutter had been the same one who had piled firewood on the Moon at the time when the Moon still paid visits to the Earth (Mazneva 1946: 108). Macedonians believe that the Moon has the face of an old village man who had recently passed away (Afanas'ev 1994: 252; Kuchta 1926: 43); the Serbians believe there is a dog's head on the Moon (Kulišić et al 1970: 201; Janković 1951: 108); a base for drying peas, according to Russians (AKTE, Arkhangelsk oblast), and also a human being who has decided to taint the Moon in order for the latter not to shine as brightly (O. Belova's note from Karelia, Kem' region). According to the beliefs of Polesie Ukrainians, there is a man with a scythe and a rake on the Moon (Belova 2004: 521), Bulgarians consider them harvesters on the field, or a shepherd with a herd of lambs (Ivanova 1937: 58), etc.

\section{ON THE FORMATION OF A MYTHOLOGICAL TEXT}

As becomes evident from this swift overview, each listed thematic group entails recurring elements forming reciprocally different combinations and regional equivalents. Together, they form a mythological text which can be simply presented as a belief, frequently in the format of allegory (e.g. a brother kills a brother), and also as a free-formatted narrative with an elaborate subject matter, often as an etiological legend with frequent apocryphal motifs entailed.

The mythological text under observation comprises several particular types of semantic elements. At first, there are characters (a smith, King David, Cain, a spinner, prophet, thief, believer of a different faith, shepherd, angel, devil, hanged person, cow, etc.), frequently occurring in pairs: two brothers, Cain and Abel, two relatives, two smiths, two emperors, father and son, man and woman, girl and boy, Jew and Gypsy, Adam and Eve, etc. The same artefacts 
occur in the different variants of interpretations (these being prevailingly the items belonging to the characters): pitchforks, shoulder poles, hammer, pot or copper bucket, dung, wood or brush, hay or straw, grain sheaves, peas, bread or dough. Likewise, the recurring properties are also represented (e.g., the rich and the poor, brothers or bridegrooms, the bright light of the Moon, lowlying Moon), reciprocal relationships between the characters (love and marriage ties of the boy and girl, and the Moon and the Sun, pairing nature of the characters), time-wise specifications (feast or Sunday while working or stealing), and, finally, the activities - functions and circumstances (governing the Moon, throwing the Moon on the Earth, spinning, weaving or sewing, fetching water, playing a musical instrument, carrying on one's back, killing, theft, hunting, water-drinking).

At the same time, the similar semantic elements in different regional customs are frequently associated with each other in a different manner, thus moulding the dialectic variants of the text and forming a distinctive semantic field concerning the spots on the Moon. Thus, the hammer occurs as a tool and a slaughtering object for the smith; the shoulder poles as the carrying device and a killing instrument for the girl fetching water; the pitchfork as the tool of the peasant (he uses the pitchfork to throw dung) and as a slaughtering device (Cain stabs Abel with the pitchfork) or even as an execution tool (a peasant hanged on a pitchfork). Manure occurs in a number of activities: it is dug with a spade, spread with a pitchfork, carried out, stolen, thrown on the Moon, the Moon smears herself with this substance). Peas are dried, stolen, planted, carried on one's back or used for covering the Moon. The cauldron (or the copper bucket) is used for fetching water, two brothers attempt to share it between themselves, Adam and Eve boil milk in this vessel. The angel and devil occur in one and the same activity as subjects and also as objects: the devil chases the angel, Archangel Michael chases the devil. A number of artefacts and characters appear as back-loads: egg basket, a bunch of pea tendrils, bundle of brushwood, trees, slain Abel. Theft is simultaneously an activity (human or lunar operation), a feature typifying the character (a thief or a girlpilferer), and also distinctive in case of several objects (stolen eggs, honey, manure, peas, ploughshare). ${ }^{4}$

\section{GEOGRAPHY OF TEXTUAL ELEMENTS}

Geographical range of the highlighted texts needs a separate analysis and interpretation. Hereby we would merely refer to the most pronounced ones from the viewpoint of the specific area: pitchforks, cow (ox), cow (ox) dung, bright 
light of the Moon, hammer, shoulder poles, poor/rich smith, fetching water, manure, spinning (weaving, sewing), theft, working on a feast, peas.

The material reveals a number of overlaps with regard to different oral heritage of Slavs, including these of Eastern, Western and Southern Slavs: 1) among the Eastern Slavs, the pitchfork is existent in case of Poles and Bulgarians; the bright light of the Moon in Southern Slavs, Russians and Poles; the cow (ox) and associated issues among Southern Slavs, Poles and Ukrainians; 2) regarding the tradition of the South-Eastern Slavs, the hammer comes across in Russians, Belorussians, Bosnians and Croatians, shoulder poles in Russians, Ukrainians and Bulgarians; the contrary pair of rich and poor occurs in the case of Ukrainians, Belorussians and Bulgarians; the smith in Serbians, Bosnians, Croatians and Russians; 3) regarding South-Western Slavs, the notion dung can be come across in Bulgarians, Macedonians, Poles and Sorbians; spinning (weaving, sewing) in Bulgarians, Macedonians, Serbs, Poles and Czechs; theft in Czechs, Poles, Sorbians and Bulgarians; 4) in the case of North-Western Slavs, working on feast-days occurs among the Poles, Sorbians and Ukrainians; peas in the tradition of Czechs, Poles and Russians.

In addition to the above-listed semantic elements it is also possible in some narratives to discern the different ways of appearing on the Moon. Sometimes, the characters appear there themselves. For instance, in the Serb tradition, an angel runs to the Moon to flee from the devil who is chasing him (Majzner 1934: 100-101; Đorđević 1958: 31; Janković 1951: 109); for Poles, Saint George jumps on the Moon as he is terrified of lightning thunderbolts (Udziela 1890: 75; Kuchta 1926: 49; Gustawicz 1901: 134-135); in the case of Russians, Cain, with the dead Abel on his back, runs far to the west where the Moon touches the Earth, and transcends to the Moon from there (Belova 2004: 506). Sometimes, the person uses special devices to reach the Moon: pursuant to the belief of Northern Russians, the girl with buckets, visible on the Moon, transcended there on the eve of yuletide, by way of an iron chain (Belova 2004: 521). Yet in some occasions, it is the Moon herself helping the characters to reach her surface: for Slovenians and Croatians, the Moon drags on to her surface a lazy workman and a girl who had been toiling on the field at night (Kuchta 1926: 43); in the case of Russians of northern regions, the moonbeams descend from the sky and suck up a boy and a girl, looking up at the Moon, as if through a trunk (VGU, Ludnikova 1923: 3) or instead, a human being gets stuck on the Moon when having decided to paint it (O. Belova's written note from Karelia, Kem' region). Likewise, ancillary powers also participate in translocating characters to the Moon: among Poles, the rainbow grabs a girl who has been living a lascivious life and takes her to the Moon (Kuchta 1926: 45); 
Tvardovski is taken there by the devil (Wójcicki 1972: 117-118; Kolbuszewski 1895: 171), or instead, Tvardovski falls on the Moon after being pushed out of the heaven by God (author's written note from the region of Chełm); in Western Ukrainians, the angel descends to the Earth, and carries and transports Abel to the Moon (Belova 2004: 506); in the case of Russians, it is God who sends Abel to the Moon (Belova 2004: 506); among Croatians, St. Peter places a smith on the moon (Đorđević 1958: 31; Janković 1951: 109); among Bulgarians, God lifts on the Moon a bride who had scolded the Moon for lying too low above the Earth (Trifonova 1945: 158) or a wizard-father, using his witchcraft powers, raises his daughter on the Moon as she had been kissing her beloved one (Pencheva 1932: 89). According to one of the Bulgarian beliefs, the spirits of brothers transcend to the Moon after death (Mikhalev: 181).

\section{RATIONALE FOR RELOCATION}

Ultimately, the texts frequently also include the underlying motivation. Punishment serves as the most frequent rationale for relocation, within the folk tradition on lunar spots and the frequently associated narratives regarding people on the Moon: killing, theft, greediness, working during feast-time, nonobedience to the parents' will, communication with the devil, pre-marital indecent behaviour, potential incest, swearing at and cursing the Moon, attacking the brightness of the Moon, and also the violation of the ban for steering at the Moon, etc. Yet the purposes of punishment are different: the smith who had taken the devil as his apprentice, and the Gipsy who had killed a next of kin have been placed on the Moon for the whole world to look at them and as a warning (Đorđević 1958: 31-32); the daughter, non-obedient to her father, in order for her secret love to become obvious (Pencheva 1932: 89); the intention in the case of Cain was to have people see his punishment and not kill each other (VEM > Ant SPM: 1; VEM > Kamanin: 236; Belova 2004: 505; Kuchta 1926: 41), and that Cain would see all the nocturnal killings and shiver of fear (clarification by the Macedonians, Tsepenkov 1894: 83; Penushliski 1969: 2526; Kuchta 1926: 40-41), in order for Cain to "cover up" and "open up" the Moon, i.e. to alter the lunar phases (explanation by Russians, VEM, Kamanin: 236-237). Likewise, it is also possible to end up on the Moon as a consequence of a curse (Mazneva 1946: 109; ArhEIM 881-II: 108; Tsepenkov 1894: 83) or by way of being commissioned by the saints to govern the Moon (Wierzchowski 1890: 189).

Less frequently, transcending to the Moon denotes an award bestowed by God: e.g., in Bosnian tradition a smith of another faith was sent there for 
respecting an alien religion, (Đorđević 1958: 31); brothers Piotr and Nikola were promoted to the Moon for having helped people (AKTE, Arkhangelsk oblast); according to the elucidation by Ukrainians, a child, sacrificed by her mother, managed to get to the Moon with an aim to achieve immortality and eternal youth so as to save the newly born Jesus (Kuchta 1926: 39-40) or, in the case of Slovenians, a working man who had left his last money to beggars, these being the embodiment of God together with angels (Kuchta 1926: 40); in Polish tradition, however, Saint George for beating the Dragon and ridding people of the relevant fear (Kolberg 1963b: 196). Preservation of one's life, or crime prevention can also be the purpose of placing a human being on the Moon: the poor brother who germinated an idea to kill his rich brother was lifted to the Moon by God (Piotrowicz 1907: 121).

Comparative analysis of the Slavic narratives on lunar spots indicates the distribution of the text into different morphological elements, making it possible to ascertain the reciprocal associations and combinations of these elements, to indicate as to how they are "assembled", constructed into texts in different regional traditions, and to determine the "grammatical" structure of the mythological text as a whole. The different elements of the text under observation may also fall into other semantic fields. Frequently, they also occur in semantic models concerning other astronomical and meteorological objects and phenomena. Thus, it is possible to come across theft, hay and next of kin in some beliefs regarding the Milky Way (a relative steals hay from another next of kin, see, e.g., Korenič 1896: 146), the pitchfork is being discussed in the folklore concerning the low-lying sky above the Earth (the sky is accidentally pierced with a pitchfork), butter-making and Gypsies in folklore narratives on mushroom rain and the rainbow (an old woman and a witch make butter, Gypsies get married), ala and a bite occur in the oral heritage narrating of the lunar eclipse (ala eats the Moon) etc.

\section{NOTES}

1 Cf. also two smiths (Bernshtam 1988: 275), a man with a hammer (Belova 2004: 521).

2 Cf. the same (a man ploughing with oxen), yet without referring to the feast in Polesie, Belorussia (Moszyński 1928: 520).

${ }^{3}$ Cf. in Greater Poland: a human being plays a harp (Kolberg 1962c: 5).

4 Similar diversity, regarding the combinations of semantic elements may also be noted in a number of other texts. E.g., the sample of semantic elements manifested 
in beliefs and folklore texts related to eagle owls (in Russian sova) also comprises motifs such as death and devouring of birds. Death appears in the interpretations of the cry of the eagle owl, characterises the condition of the eagle owl throughout the day, and applies itself in the case of his brother, boreal owl (in Russian filin, who dies, according to folk tradition). In connection with the devouring of birds, the eagle owl occurs in the folklore as a subject (is awarded a right to eat birds) and as an object (the goshawk gorges baby owls as the most bastardly of baby birds). (Further, see Gura 1997: 568-586)

\section{ARCHIVE SOURCES}

\section{AIF - Archives of the Folklore Institute at the Bulgarian Academy of Sciences in Sofia:}

AKTE = Astronomical card index of the toponymic expedition, Chair of Russian Language and General Linguistics, Ural State University.

Anchev, A. 1980. Folklore materials from Vinarsko village, Aytos municipality, Burgas region. AIF No. $215 \mathrm{I}$.

Mikhailova K. 1985. Folklore materials from Slaveevo, Drabshina, Svirachi and Oreshino villages, Ivaylovgrad municipality, Khaskovo region. AIF I No. 47-II.

\section{ArhEIM - Archives of the Institute of Ethnography at the Bulgarian Academy of Sciences in Sofia:}

Georgieva, I. 1971. Naroden mirogled (materjali). Burgas, Varna and Silistra regions. ArhEIM No. 576-II.

Georgieva, I. 1972. Naroden mirogled. Petrich municipality, Blagoevgrad. ArhEIM No. 776-II.

Stamenova, Zh. A. 1977. Svetogled, narodni znaniia i viarvaniia: (Materiali ot selata v Plovdivski raion, na iug ot r. Maritsa). Plovdiv municipality, Plovdiv region. ArhEIM No. 878-II.

Stamenova, Zh. A. \& Koleva, T. A. 1972. Svetogled, narodni znaniia i viarvaniia: (Materiali ot selata v Karlovski raion). Plovdiv region. ArhEIM No. 881-II.

Stamenova, Zh. A. \& Koleva, T. A. 1974. Svetogled, narodni znaniia i viarvaniia: (Materiali ot selata v Karlovski raion). Plovdiv region. ArhEIM No. 880-II.

Stamenova, Zh. A. \& Koleva, T. A. 1977. Svetogled, narodni znaniia i viarvaniia: (Materiali ot selata v Plovdivski raion, na sever ot r. Maritsa). Plovdiv municipality, Plovdiv region. ArhEIM No. 879-II.

PA = Polesie archive of the Department of Ethnolinguistics and Folklore, Institute for Slavic Studies, Russian Academy of Sciences, Moscow.

PTA EI = Archive of the Institute of Ethnology and Cultural Anthropology, Polish Academy of Sciences:

Archiwum materiałów terenowych Zakładu Etnografii Instytutu Historii Kultury Materialnej. ArchIHKM 1145-I. Pow. Ostrołęka, w. Wach. 1953. 


\section{RKA = Archive of the Chair of Slavic Ethnography, Jagielloński University, Krakow: \\ Atlas kultury ludowej. [Atlas of Folk Culture.] Materials collected for the K. Mosziński programme. Woźniak, J. Kultura duchowa, w. Tryńcza, gm. Tryńcza, woj. Przemyskie. 1988. Archiwum Katedry Etnografii Słowian Uniwersytetu Jagiellońskiego (Kraków), 8643.}

\section{ADP - Sofia University Library “St. Kliment Ohridski”, archive of diploma pa-} pers supervised by academician $\mathbf{S}$. Romanski:

Arakchieva, M. 1939 Etnografsko izsledvane na s. Vratsa Kiustendilsko. Manuscript 357.

Fand"kova, M. 1937 Etnografsko izsledvane na s. Bulchino, Aitosko. Manuscript 322.

Iavashev, R. I. 1937. Etnografiia i govor na s. Sukhindol, Sevlievsko. Manuscript 277.

Ilieva, V. S. 1941. Etnografsko izsledvane na selo Golintsi, Lomsko. Manuscript 163.

Ivanova, M. M. 1937. Etnografsko izsledvane na selo Gabare, Beloslatinsko. Manuscript 330.

Kasabova, N. 1940. Etnografsko izsledvane na b"lgarite ot selo Enik'oi, Uzunkupriisko, preseleni v selo Sinapovo, Elkhovsko. Manuscript 281.

Khristova, T. M. 1941. Etnografsko izsledvane na s. Pokrovnik, Gornodzhumaisko, Sofiiska oblast. Manuscript 1.

Kr"steva, M. P. 1943. Etnografsko izsledvane na s. Tagarevo, Sredetsko. Manuscript 91

Kunov, D. S. 1940. Etnografsko izsledvane na selo Dobrolevo, Orekhovska okoliia. Manuscript 259.

Mazneva, L. Kh. 1946. Etnografsko izsledvane na selo Od"rne, Plevenska okoliia. Manuscript 55.

Mikhalev, D. T. s.a. Etnografsko i ezikovo izsledvane na s. Beltsov, Belensko. Manuscript 367.

Milenkova, A. S. 1943. Etnografsko izsledvane na selo Dobrina, Provadiisko. Manuscript 187.

Nenov, S. N. 1939. Etnografsko izsledvane na s. Kitino, Omortagsko. Manuscript 286.

Pasheva, M. 1938. Etnografsko i ezikovo izsledvane na selo Nevestino, Karnobatsko. Manuscript 83.

Pencheva, N. A. 1932 Etnografsko izsledvane na selo Atanask'oi, Burgaska okoliia. Manuscript 254.

Pencheva, N. I. 1940. Etnografsko izsledvane na s. Et"r i okolnite sela, Gabrovsko. Manuscript 167.

Trifonova, V. D. 1945. Etnografsko izsledvane na s. Mikhaltsi, Pavlikensko. Manuscript 20.

V"glenov, M. Kh. 1936. Izsledvane na bita, nravite, obichaite i govora na s. Sr"be, Sevlievsko. Manuscript 271.

Velcheva, V. I. s.a. Etnografsko izsledvane na selo Zverino, Vrachansko. Manuscript 34 . 


\section{VEM - The Russian Museum of Ethnography:}

Antipov, V. - Suevernye predstavleniia o mirozdaniia. Demonologiia. Sueveriia, sviazannye s bytom. (Cherepovets municipality, Novgorod gubernia). Arch. fund 7 (Prince V. N. Tenishev's ethnographic bureau), list 1, file 798, p. 14.

Kamanin, P. M. Pover'ia, zagovory, obriady, primety. Rody i ukhod za rebenkom. Bolezni i ikh lechenie. Letargiia. Predstavlenie o smerti. Pogrebal'nye obychai. Pochitanie prazdnikov. Arch. fund 7 (Prince V. N. Tenishev's ethnographic bureau), list 1, file 29, p. 58.

\section{VGU - Archive of the Russian Geographical Society:}

Ludnikova, A. F. Legendy, zapisannye v s. Oksino Pechorskogo u. Arkhangel'skoi gub. [Legends, recorded in Oksino village, Pechora municipality, Arkhangelsk gubernia.] Arch. fund 1, list 1, file 130, p. 4 [1923].

\section{REFERENCES}

Afanas'ev, Aleksandr N. 1994. Poeticheskie vozzreniia slavian na prirodu. [Poetic Views of the Slavs towards nature.] Opyt sravnitel'nogo izucheniia slavianskikh predanii i verovanii v sviazi s mificheskimi skazaniiami drugikh rodstvennykh narodov 3. Moscow: Indrik [reprint].

Agapkina, Tat'iana 1993. "Neskazochnaia proza" i paremiia. [Non-fictional Prose and Paroemia.] In: S. Tolstaia \& T. Tsiv'ian (eds.) Slavianskoe i balkanskoe iazykoznanie: Struktura malykh fol'klornykh tekstov. Moscow: Nauka, pp. 152-159.

Belova, Ol'ga (ed.) 2004."Narodnaia Bibliia": Vostochnoslavianskie etiologicheskie legendy. ["Folk Bible": Etiological Legends of the Eastern Slavs.] Traditsionnaia dukhovnaia kul'tura slavian: Publikatsiia tekstov. Moscow: Indrik.

Bernshtam, Tat'iana 1988. Molodezh'v obriadovoi zhizni russkoi obshchiny XIX-nachala XX v.: Polovozrastnoi aspekt traditsionnoi kul'tury. [Young People in the Ritual Life of the Russian Peasant Community in the $19^{\text {th }}$ and Early $20^{\text {th }}$ Centuries: the Age and Gender Aspect of Traditional Culture.] Leningrad: Nauka.

Ciszewski, S. 1887. Lud rolniczo-górniczy z okolic Sławkowa w powiecie Olkuskim. Zbiór wiadomości do antropologii krajowej 11. Kraków, pp. 1-129.

Czerny, Adolf 1895. Istoty mityczne Serbów Łużyckich 10. [Translated from Sorbian by Grabowski, B.] Warszawa: Wisła, pp. 54-97, 245-281, 531-563.

Dal', Vladimir 1957. Poslovitsy russkogo naroda. [Russian Proverbs.] Moscow: Khudozhestvennaia literatura.

Đorđević [Djordjevic], Tihomir 1958. Priroda u verovanju i predanju našega naroda 1. Srpski etnografski zbornik, LXXI. Beograd.

Eljasz-Radzikowski, S. 1899. Z folklorystyki słowackiej. Lud 5: 3, 4. Lwów, pp. 238255, 297-320.

Federowski, Michał 1897. Lud białoruski na Rusi litewskiej. Materyjały do etnografii słowiańskiej zgromadzone w latach 1877-1891. 1: Wiara, wierzenia i przesądy ludu z okolic Wołkowyska, Słonima, Lidy i Sokółki. Kraków.

Fischer, A. 1909. Uzupełnienia Dähnhardta. Lud 15: 4. Lwów, pp. 320-339.

Georgieva, Ivanichka 1983. B"lgarska narodna mitologiia. Sofia: Nauka i izkustvo. 
Gura, Aleksandr 1997. Simvolika zhivotnykh v slavianskoi narodnoi traditsii. [Animal Symbols in Slavic Folk Tradition.] Traditsionnaia dukhovnaia kul'tura slavian: Sovremennye issledovaniia. Moscow: Indrik.

Gustawicz, B. 1901. O ludzie Podduklańskim w ogólności, a Iwoniczanach w szczególności. (Cześć wtóra). Lud 7: 1-4, pp. 43-54, 128-146, 241-256.

Haupt, Joachim Leopold \& Schmaler, Johann Ernst 1953. Volkslieder der Sorben in der Ober- und Nieder-Lausitz. Anastatischer Neudruck. Berlin: Akademie-Verlag.

Janković, Nenad 1951. Astronomija u predanjima, običajima i umotvorinama srba. [Astronomy in the Lore, Customs, and the Folk Wisdom of the Serbians.] Srpski etnografski zbornik, LXIII. Beograd: Naučna knjiga.

Kolchin, A. 1899. Verovaniia krest'ian Tul'skoi gubernii. Etnograficheskoe obozrenie 3, pp. 1-60.

[Kolbuszewski, E.] E. K. 1895. Gwiazdy i grzyby w podaniach ludu (Szkic etnologiczny). Lud 1: 6, 7, 8. Lwów, pp. 168-178, 197-207.

Kolberg, Oskar 1962a. Kujawy - 1. Dzieła wszystkie 3. Wrocław \& Poznań.

Kolberg, Oskar 1962b. Krakowskie - 1. Dzieła wszystkie 5. Wrocław \& Poznań.

Kolberg, Oskar 1962c. W. Ks. poznańskie - 7. Dzieła wszystkie 15. Wrocław \& Poznań.

Kolberg, Oskar 1962d. Lubelskie - 2. Dzieła wszystkie 17. Wrocław \& Poznań.

Kolberg, Oskar 1963a. Kujawy - 3. Dzieła wszystkie 3. Wrocław \& Poznań.

Kolberg, Oskar 1963b. Kieleckie - 2. Dzieła wszystkie 3. Wrocław \& Poznań.

Korenić, S. 1896. Život, jezik i običaji Stupničana kraj Zagreba. Zbornik za narodni život i običaji Južnih Slavena 1. Zagreb, pp. 119-151.

Kuchta, Jan 1926. Polskie podania ludowe o człowieku na księżycu. Lud II: 5 (25). Lwów \& Warszawa \& Kraków \& Poznań \& Wilno, pp. 38-51.

Kulišić, Špiro \& Petrović, Petar Ž. \& Pantelić, Nikola 1970. Srpski mitološki rechnik. Beograd: Nolit.

Majzner, Milan 1934. Srpske narodne pripovetke. Srpski etnografski zbornik, L: Rasprave i građa 1. Beograd: Srpska kraljevska akademija, pp. 95-154.

Markevich, Nikolai 1860. Obychai, pover’ia, kukhnia i napitki malorossiian. Kiev.

Moszyński, Kazimierz 1928. Polesie Wschodnie. Materjały etnografuczne z wschodniej części b. powiatu mozyrskiego oraz powiatu rzeczyckiego. Warszawa.

Nikiforovskii, Nikolai 1897. Prostonarodnye primety $i$ pover'ia, suevernye obriady $i$ obychai, legendarnye skazaniia o litsakh i mestakh. Vitebsk: Gubernskaia tipografiia.

PAE = Polski atlas etnograficzny . Index file. Institute of History of Material Culture . Department of Ethnography.

Penushliski, Kiril (compiler and ed.) 1969. Predanija i legendi. [Beliefs and Legends.] Skopje: Makedonska kniga.

Piotrowicz, S. 1907. Znachorka i wróżka Jewdokia Bojczuk: Materyały folklorystyczne ze wsi Bortnik na Pokuciu. Lud 13: 2, 3. Lwów, pp. 118-129, 216-232.

Rikhlik, Yevgen 1928. "Lud". Serja II. Tom V, zeszyt I-IV. Rok 1926 (144+XVIII). Etnografichnyi visnyk 7. Kiev, pp. 213-215.

Rodopi 1994 = Popov, R. (ed.-in-chief). Rodopi: Traditsiona narodna dukhovna $i$ sotsialnonormativna kultura. Sofia: Izdatelstvo na BAN.

Savchenko, I. 1906. Mirosozertsanie nashikh prostoliudinov-malorussov. Zhivaia starina 2, pp. 105-108. 
Siarkowski, W. 1885. Materyjały do etnografii ludu polskiego z okolic Pinczowa. Zbiór wiadomości do antropologii krajowej 9. Kraków: Drukarnia Uniwersytetu Jagiellońskiego, pp. 3-72.

SSS (Dictionary of Stereotypic Symbols) = Bartmiński, Jerzy \& Niebrzegowska, Stanisława (ed.) 1996. Słownik stereotypów i symboli ludowych 1: Kosmos. [1:] Niebo. Światła niebieskie. Ogień. Kamienie. Lublin: UMCS.

Sychta, Bernard 1967-1976. Słownik gwar kaszubskich na tle kultury ludowej 1-7. Wrocław \& Warszawa \& Kraków \& Gdańsk: Zakład Narodowy im. Ossolinskich.

Szyfer, Anna 1975. Zwyczaje, obrzędy i wierzenia Mazurówi Warmiaków. Wyd. 2 poszerzone. Olsztyn (Rozprawy i materiały Ośrodka badań naukowych im. Wojciecha Kętrzyńskiego w Olsztynie, nr 50).

Telbizov, Karol \& Vekova-Telbizova, Mariia 1963. Traditsionen bit i kultura na banatskite b"lgari. Sbornik za narodni umotvoreniia i narodopis 51. Sofia: BAN.

Tolstaia, Svetlana 1995. Vidov den'. In: N. Tolstoi (ed.) Slavianskii drevnosti: Etnolingvisticheskii slovar' 1. [Slavic Antiquities. Ethno-Linguistic Dictionary.] Moscow: Mezhdunarodnye otnosheniia, pp. 369.

Tsepenkov, M. 1894. T"lkuvaniia na prirodni iavleniia, razni narodni viarvaniia i prokobiavaniia. Ot Prilep. Sbornik za narodni umotvoreniia, nauka i knizhnina 11. Sofia, pp.73-84.

Udziela, S. 1886. Materjały etnograficzne zebrane z miasta Ropczyc i okolicy. Zbiór wiadomości do antropologii krajowej 10. Kraków: Drukarnia Uniwersytetu Jagiellońskiego.

Udziela, S. 1890. Lud Polski w powiecie Ropczyckim w Galicyi. Zbiór wiadomości do antropologii krajowej 14. Kraków: Drukarnia Uniwersytetu Jagiellońskiego, pp. $1-136$.

Vakarelski, Khristo 1977. Etnografiia na B"lgariia. Vtoro izdanie. Sofia: Nauka i izkustvo.

Wasilewski, Jerzy S. 1989. Tabu a paradygmaty etnologii (rozprawa habilitacyjna). Warszawa: Uniwersytet Warszawski.

Wierzchowski, Z. 1890. Materyjały etnograficzne z powiatu Tarnobrzeskiego i Niskiego w Galicyi. Zbiór wiadomości do antropologii krajowej 14. Kraków: Drukarnia Uniwersytetu Jagiellońskiego, pp. 145-211.

Wójcicki, Kazimierz Władysław 1972. Klechdy, starożytne podania i powieści ludu Polskiego i Rusi. Zebrał i spisal K. W. Wójcicki, wybór i opracowanie Ryszarda Wojciechowskiego, słowo wstępne Juliana Krzyżanowskiego. Warszawa: Państwowy Instytut Wydawniczy.

Zaglada, Nina [Leonila] 1929. Pobut selians'koyi dytyny. Materiialy do monografiyi s. Starosillia. Materiialy do etnol'ogiyi, I. Kiev.

Zelenin, Dmitrii 1914. Opisanie rukopisei Uchenogo arkhiva Imperatorskogo Russkogo geograficheskogo obshchestva 1. [List of manuscripts in the Research Archives of the Imperial Geographical Society in Russia.] Petrograd: Imperatorskoe Russkoe Geograficheskoe Obshchestvo.

Zelenin, Dmitrii 1991. Vostochnoslavianskaia etnografiia. [Ethnography of Eastern Slavs.] Moscow: Nauka. 